\title{
THE NEW MYTHOLOGY OF SCHOOL DESEGREGATION*
}

\author{
Willis D. Hawley $\dagger$
}

\section{INTRODUCTION}

Once upon a time, not so long ago, it seemed clear that to desegregate the schools was the right thing to do. But a funny thing happened on the twentyyear journey from the South to the North. The moral imperative and great hopes that gave momentum to desegregation efforts seem to have been replaced by a combination of pessimism and pragmatism. The old mythology held that children of all colors learning side by side would bring about the end of prejudice and would substantially undermine social inequalities. This faith has apparently given way to a new mythology, which holds that we have tried our best, but the costs of imposing desegregation on an unwilling community generally outweigh the benefits. Of course, few people argue that clear-cut efforts to keep minority children from going to school with white children should be tolerated. But this form of discrimination, it is widely believed, is now largely a matter of history.

The weakening commitment to school desegregation has many sources, including the practical difficulties of desegregating cities with small and dwindling proportions of white public school students and the feelings of some black and Hispanic leaders that their energies are best spent on improving "their own" schools. But behind the decline in conviction that school integration is a high priority for the society is the belief that desegregation "doesn't work."

To be sure, many cities now have fewer whites living in them than were there before desegregation began. And many parents who have been motivated by the experience of desegregation to look closely at schools (often for the first time) have had their fantasies about the quality of the schools punctured. These negative impressions have been enhanced and given legitimacy by some researchers whose studies seem to show that, at best, little is to be gained by desegregating schools. Thus, with the help of some social scientists

\footnotetext{
* Portions of an earlier version of this article appeared in Hawley, Getting the Facts Straight About the Effects of School Desegregation, 36 Educ. Leadership 314 (1979); Hawley, The Fragile Truth Behind School-Integration Myths, Los Angeles Times, March 11, 1979, Part IV, at 3. This paper has benefitted from the work of the members of the National Review Panel on School Desegregation Research. I am especially grateful to Paul Wortman. Christine Rossell, and John McConahay, who provided detailed comments on an earlier version of this paper.

$\dagger$ Associate Professor of Policy Sciences and Political Science, Duke University; Director, Center for Educational Policy, Duke University Institute of Policy Sciences and Public Affairs.
} 
and their popularizers, the issue of school desegregation is being transformed from a quest for social justice and interracial understanding to a practical search for ways to improve basic education and avoid conflict. This transformation is being facilitated by many political leaders who see support for desegregation-except in principle-as a sure source of forced retirement from public office.

Myths are beliefs in the way things are, have been, or should be. They may be largely true or largely false, or they may be so thoroughly infused with preferences that they are beyond objective analysis. Myths usually develop and persist to serve the needs people have for guidelines in dealing with complicated problems. This article calls into question the new mythology of school desegregation. In particular, I hope to show that the available research has been misinterpreted and misused. Indeed, rather than supporting the idea that desegregation is harmful or at best nonproductive, the social science research provides a basis for believing that: (1) on balance, desegregation has resulted in positive outcomes for children and the society; and (2) it is increasingly possible to identify the conditions and practices that enhance the potential benefits of desegregation for both whites and minorities.

My objective is not, however, to defend the old mythology. The view that desegregation is the ticket to the promised land does not fit the accumulated evidence. It does not seem reasonable to argue that desegregation will always have positive consequences, nor to believe that even in the best of circumstances desegregation will, in itself, totally eliminate differences and tensions between races that have deep roots in historic patterns of prejudice and social inequality. But while the old mythology claimed too much for desegregation, the new mythology represents a misunderstanding of and an overreaction to what has occurred in desegregating communities.

The Tenets of the New Mythology

The specific beliefs that make up the new mythology of desegregation seem to be the following:

1. Desegregation generally does not enhance the academic achievement of minorities and indeed may impede the cognitive development of minorities and of whites in many cases.

2. Desegregation increases interracial conflict and prejudice in schools, communities, and the society at large.

3. Desegregation is harmful to the development of self-esteem, aspirations to achieve, and racial and ethnic identity among minorities.

4. Busing children beyond the school nearest their home is harmful to their performance in school, destructive of a sense of community cohesion, and very costly in financial terms. 
5. Desegregation does not enhance the post-high school opportunities and socioeconomic status of minorities.

6. Desegregation leads to white flight, which reduces the social class and racial heterogeneity of communities, thus eliminating the long-run opportunities for racial desegregation.

The believers themselves often link the components of this mythology. For example, James Coleman bases his argument for realistic and basically voluntary desegregation plans on the evidence that desegregation generally does not enhance the academic achievement of minorities and that many whites will leave the public schools rather than be forced to send their children to desegregated schools. ${ }^{1}$

This article examines the validity of the tenets of the new mythology of school desegregation by comparing them to the findings of the available research on the effects of desegregation. My objective is not to show that these six beliefs are false, though some appear to be, but to show that the beliefs are not demonstrably true. If the beliefs upon which the new mythology rests are questionable, they can provide no basis for the argument that we should pursue desegregation only where it can be achieved without disruption, conflict, and significant financial costs.

\section{Research Findings and the New Mythology}

There are considerable difficulties in interpreting the research on school desegregation, and these problems are increased by the way advocates on all sides of the desegregation issue use the research in debates over policy alternatives. The National Review Panel on School Desegregation ${ }^{2}$ has undertaken a systematic assessment of the findings from social science research on academic achievement, racial identity and self-concept, race relations, post-high school opportunities, and community conflict, "white flight," and busing. In addition, the Panel has analyzed the political uses of desegregation research and examined the administrative and instructional practices that may enhance the possibilities that desegregation will have positive outcomes for students. The Panel's work provides a basis for evaluating the new mythology of school desegregation.

1. Coleman, Can We Integrate Our Public Schools without Busing?, Chicago Tribune, Sept. 17, $1978, \S 2$, at 1,5 .

2. The studies undertaken by the Panel appear in 42 Law \& Contemp. Prob., Summer 1978; 42 Law \& Contemp. Prob., Autumn 1978. For lists of members of the panel and the advisory committee to the panel, for further discussion of the panel formation, see Foreword, 42 LAw \& Contemp. Prob., Summer 1978 at $1,9$. 


\section{A. Myth I: \\ Desegregation generally does not enhance the academic achievement of minorities and may in some cases impede their learning}

Before examining the effects of desegregation on minorities, it should be noted that virtually every researcher who has examined the impact of desegregation on white children finds that their academic achievement, as measured by conventional standardized tests, is not negatively affected. ${ }^{3}$

Bridge, Judd, and Moock have recently completed a careful assessment of the major input-output studies of minority academic achievement. ${ }^{4}$ They found, with one exception, which dealt with students not desegregated until the junior high level, that blacks' test performance is higher in predominantly white schools. One other input-output study, by Robert Crain and Rita Mahard, examined data from the National Longitudinal Study of the high school class of 1972 and found that in the North black achievement tends to increase as the proportion of white students in school increases, but in the South attending predominantly white schools does not significantly affect black achievement. ${ }^{5}$ They suggest that the reason for this regional difference may be that the majority of the seniors tested in the Southern schools had attended segregated schools most of their lives. ${ }^{6}$ Although input-output studies have methodological limitations for assessing the effects of desegregation, ${ }^{7}$ the

3. See, e.g., Crain \& Mahard, Desegregation and Black Achievement: A Review of the Research, 42 Law \& Contemp. Prob., Summer 1978, at 17 [hereinafter cited as Crain \& Mahard, Desegregation and Black Achievement].

4. School desegregation studies dealing with minority achievement are of two general types, (a) "input-output" studies, such as the so-called Coleman Report, in which the racial composition (and other school characteristics) is correlated with test scores across districts without the researchers being concerned how or when schools came to have a particular racial mix and (b) studies of particular school systems. G. Bridge, C. Judd, \& P. Moock, The Determinants of Educational Outcomes: The Effects of Families, Peers, Teachers, and Schools (forthcoming). For a discussion of the research methodology on desegregation and minority achievement, see Crain \& Mahard, Desegregation and Black Achievement, supra note 3, at 17-56. The literature on input-output studies is reviewed in M. Weinberg, Minority Students: A Research Appraisal (1977); N. St. John, School Desegregation: Outcomes for Children (1975).

5. Crain \& Mahard, School Racial Composition and Black College Attendance and Achievement Test Performance, 51 Soc. of Evuc. 81 (1978). The National Longitudinal Study is described in W. Fetters, National longitudinal Study of the High School Class of 1972: Comparative. Profiles One and One-Half Years After Graduation (1975).

6. Crain \& Mahard, School Racial Composition, supra note 5, at 99.

7. "[I]nput-output studies present some methodological problems, including that of how to control for background factors. In most of these studies, the black students who attend predominantly white schools are of higher socioeconomic status than those in segregated schools. When this is the case, the use of a pretest score or a measure of socioeconomic status as a control does not remove all of the differences in achievement related to background. . . A second problem is that of bias due to self-selection. If black parents who move into integrated neighborhoods are more motivated to advance the achievement of their children than parents who remain in segregated neighborhoods, a bias is introduced that cannot be easily eliminated." Crain \& Mahard, Desegregation and Black Achievement, supra note 3, at 17. 
fact that most of these studies find a positive effect on black achievement is significant.

Because input-output studies that simply compare student characteristics and aggregate-level school characteristics with test scores usually do not provide much information on the nature of the desegregation experience, Robert Crain and Rita Mahard have reviewed the studies of particular communities that have developed explicit desegregation plans. ${ }^{8}$ Of seventy-three studies, they found forty in which desegregation had a positive effect on black achievement, twenty-one with little or no effect, and only twelve with a negative result. ${ }^{9}$

A substantial proportion of the studies showing negative or negligible effects of desegregation on black achievement deal with high school-age youths. Yet is is almost certain that the earlier black children experience desegregation (optimally, in kindergarten), the more likely it is that desegregation will have positive effects. ${ }^{10}$ The National Assessment of Educational Progress found that between 1969 and 1973, while a substantial amount of desegregation was taking place in the South (but not in the North), the achievement gains for black nine-year-olds in the South increased ${ }^{11}$ while scores for the nation as a whole declined, and the black-white achievement gap declined in the South. The trend did not hold for older children who had experienced desegregation at later grades. ${ }^{12}$

Contrary to the view proffered by those who argue that desegregation is not worth the cost, mandatory desegregation plans appear more likely than voluntary desegregation to produce positive effects for blacks, especially in the North. ${ }^{13}$ School systems forced to desegregate by some higher unit of government or by the courts may plan more carefully, develop programs that are more responsive to student and teacher needs, and, in some cases, receive additional aid (such as Federal Emergency School Assistance Act funds) to provide useful facilities and services. This is not to argue that mandatory desegregation should be preferred, though these findings do suggest that forcing people to desegregate does not eliminate the benefits that desegregation might hold and that making desegregation-or any other new educational policy-work requires commitment, planning, and persistence.

In summary, Myth $\mathrm{I}$ is not generally true. While it is possible to identify

8. Id. at 17 .

9. Id. at Table 2.

10. See id. at Table 4.

11. S. Johnson, Update on Education: A Digest of the National Assessment of Educational Progress (Education Committee of the States Report, 1975) (ERIC Doc. No. 013381 ).

12. See id.

13. See Crain \& Mahard, Desegregation and Black Achievement, supra note 3, at nn. I30-36 \& ac companying text. 
circumstances in which the myth would be fulfilled, the evidence provides every reason to believe that in most, if not all, communities it is possible to design and implement desegregation plans that will have positive effects on the achievement of minorities. ${ }^{14}$ But it is also clear that simply mixing children of different races will not necessarily bring positive results. Achievement will depend on such factors as the achievement levels of the children involved, the teacher behavior and instructional strategies students experience, and the character of race relations in the school and community.

\section{B. Myth II: \\ Desegregation increases interracial conflict in school, communities, and the society at large}

If proponents of school desegregation have had one great hope, it is that the policy would lead to the end of prejudice and discrimination based on interracial differences. Some see the community conflict that often occurs in the face of court-ordered desegregation, the interracial disorders that sometimes occur in desegregating schools, and the antibusing sentiment in the nation as a whole as evidence that school desegregation is counterproductive of good race relations.

In a review of studies related to the impact of desegregation on adult opinion, Christine Rossell concludes that the nationwide reduction in school desegregation has been associated with dramatic reductions in racial intolerance over the last several years. More specifically:

1. There is overwhelming and increasing support for the principle of racial integration and racially balanced schools, with the increase in support for school integration greatest in the South, where there has been the greatest amount of court-ordered desegregation. Parents of public school children who attend desegregated schools are more likely than other adults to have more positive attitudes toward desegregation. At the same time, whites are overwhelmingly opposed to busing as a means to desegregate the schools.

2. In most communities, the prominence of the "busing problem" in the public mind and its prominence as a political issue begins to recede by the end of the first year of implementation. There is still polarization

14. It seems possible that where higher achieving students of a given race are in classrooms in which most students are of another race and the dominant group is low achieving, the achievement level of the high achievers will go down. There appear to be no studies of desegregated schools that actually make this link, but it seems to fit some general evidence on the effects of classroom contexts. It may also be that in classrooms wtih bipolar distributions of academic ability, the low achievers will lose self-esteem when school practices draw attention to differences in ability, especially if such differences are correlated with ethnicity. 
over racial issues at the end of the second year of desegregation in school districts where a great deal of violence and controversy was associated with desegregation. Most whites, however, feel their relations with blacks are friendly or neutral despite the desegregation controversy.

3. Both blacks and whites greatly overestimate their neighbors' opposition to securing racial balance in the public schools. ${ }^{15}$

Another recent study, by Jacobsen, suggests that court orders may actually diminish opposition to busing among parents. ${ }^{16}$

There is no doubt that desegregated schools experience greater interracial disruptions than segregated schools; how could it be any other way? But desegregation does not appear to be a major cause of school violence. The massive Safe School Study found that despite the attention the media have given to the violence accompanying the desegregation process,

A school's being under court order to desegregate is associated with only a slight increase in the amount of student violence when other factors are taken into account .... The statistical analysis shows further that there is no consistent association between the number of students bussed and school violence, controlling for other factors. Finally, there is a weak association between student violence and the recentness of initial desegregation efforts at a school. Together these findings suggest that some violence may be due to the initiation of mandatory desegregation, but that as time goes on and larger numbers of students are bussed to achieve racial balance the desegregation process ceases to be a factor. ${ }^{17}$

Of course, to say that desegregation does not result in interracial conflict is not to say that it promotes good race relations. But it does without doubt provide opportunities for interracial interaction that are not otherwise possible. The questions then are whether interracial interactions actually occur, and whether they are essentially friendly and positive.

All of the relevant studies indicate that desegregation increases interracial contacts among students. For example, in the Louisville-Jefferson County schools, where desegregation initially resulted in considerable community conflict, 65 percent of the white students and 65 percent of the black students reported more interaction with peers of the other race. ${ }^{18}$ The available research

15. Rossell, School Desegregation and Community Social Change, 42 LAw \& Contemp. Prob., Summer 1978 , at 133-183.

16. Jacobsen. Desegregation Rulings and Public Attitude Change: White Resistance or Resignation?, 84 AM. J. Soc. 698 (1978).

17. 1 National Institute of Education, Violent Schools-Safe Schools: The Safe School Study Report to the Congress 132 (1978).

18. McConahay \& Hawley, Attitudes of Louisville and Jefferson County Public School Students Towards Busing for School Desegregation: Preliminary Results 22 (Nov. 1976) (working 
is unclear, however, on how the rate of interaction is affected by variations in the racial mix of schools and classrooms. It may be that when any group comprises a very small proportion of a school or classroom, less than 10 percent for example, interracial contacts will be disproportionately lower than when that racial group is larger in number. The available evidence, however, is inadequate to verify this speculation or to predict the outcome when students of different races and social classes are involved. ${ }^{19}$ Since the measures commonly used to assess racial interaction involve essentially friendly relationships (work partner choices or seating patterns, for example), it follows that most reported interracial interactions are positive ones. The Louisville study distinguished between the volume and character of interracial contacts. In this conflictridden community, only 14 percent of the whites and 4 percent of the blacks reported that their contacts with the other race were "not friendly." 20 In the Riverside study, the data show that the likelihood that an Anglo will choose minority friends and schoolwork partners is greater after desegregation than before, though cross-race preferences declined somewhat over a three year period. ${ }^{21}$ It should be noted that the Riverside study, along with many others, seeks to discover the extent of "racial cleavage" by a measure that forces students to make a limited number of choices for interaction, and thus choose among races. The research indicates that even in the best of circumstances, intra-racial interactions and friendship choices substantially exceed the volume of interracial relations, but this, as compared with segregation, is not evidence of interracial conflict. ${ }^{22}$

It is obvious that school desegregation has fallen far short of the hopes

paper, Duke University Institute of Policy Sciences and Public Affairs) (hereinafter cited as McConahay \& Hawley, Preliminary Results].

19. Shaw found that as the proportion of blacks declined (from $24 \%$ to $15 \%$ ), interracial interactions increased. Shaw, Changes in Sociometric Choices Following Forced Integration of an Elementary School, 29 J. Soc. Issues No. 4, at 143, 151-56 (1973). On the other hand, a study by St. John and Lewis suggests that when either black or white males are in classrooms where they comprise a small proportion of the student body, they are less likely to be popular with students of the other race. This finding was reversed for black girls, however. Lewis \& St. John, Contribution of Cross-Racial Friendship to Minority Group Achievement in Desegregated Classrooms, 37 Soc1ometrY 79 (1974). Hawley studied 79 classrooms in North Carolina and found that interracial contacts were largely unaffected by racial composition though they were somewhat less frequent in classrooms that were 81 to $100 \%$ white. Hawley, Teachers, Classrooms, and the Effects of School Desegregation on Effort in School: A Second Generation Study 28 (April 1976) (Working Paper No. 4763, Duke University Institute of Policy Sciences and Public Affairs). The probability of black contact with whites, assuming constant levels of prejudice, "naturally" increases as the number of black peers declines.

20. McConahay \& Hawley, Preliminary Results, supra note 18, at 23.

21. H. Gerard \& N. Miller, School Desegregation: A Long-Term Study ch. 10 (1975).

22. McConahay, The Effects of School Desegregation upon Students' Racial Attitudes and Behavior: A Critical Review of the Literature and a Prolegomenon to Future Research, 42 LAw \& Contemp. ProB., Summer 1978 , at 77 . 
most of its proponents have had for its potential to end interracial prejudice. But it is also clear that the idea that desegregation has increased conflict and prejudice in schools, communities, and the society at large is largely without substance.

Interracial conflict can only occur when races interact, and thus desegregated schools will experience more overt tension between races than will segregated schools. Yet interracial contact is an essential step in establishing positive and stable race relations. Much can be done to minimize tensions related to desegregation and to turn opportunities for greater interracial contact into situations where attitudes and behaviors toward other races can be substantially improved. Almost all researchers acknowledge the positive influence of such steps as desegregation at early ages, classroom practices that foster interracial interactions, efforts to eliminate teacher bias, strong leadership by principals, and noncompetitive reward systems and learning situations. ${ }^{23}$

\section{Myth III:}

Desegregation is harmful to the self-concept and the racial and ethnic identity of minorities 24

The concern implicit in this set of beliefs is now most often expressed by racial and ethnic minorities. Some Hispanic leaders are particularly concerned about the apparent incompatibility in many communities of desegregation and bilingual education programs (which they believe support ethnic identity and thus foster a strong self-concept). The only research on the effects of desegregation on the personality and ethnic identity of Hispanics appears to be the Riverside, California, study. Gerard, Miller, and their associates conclude that after three years, desegregation had no effects on the sense of selfesteem or confidence in academic ability of Hispanics (in this case, Mexican Americans). ${ }^{25}$ They also found among the Hispanics no lessening of willing-

23. This is only a very partial list. These and other research-grounded steps for enhancing race relations in schools are discussed in Chesler, Crowfoot \& Bryant. Institutional Changes to Support School Desegregation: Alternative Models Underlying Research and Implementation, 42 LAw \& Contemp. Prob., Autumn 1978, at 174; Schofield, School Desegregation and Intergroup Relations, in Social Psychology of Education: Theory and Research 329 (D. Bar-Tal \& L. Saxe ed. 1978); Stephan \& Rosenfield, Effects of Desegregation on Racial Attitudes, 36 J. Personality \& Soc. Psych. 795 (1978); G. Forehand \& M. Ragosta. A Handbook for Integrated Schooling (Office of Education Report No. ETS-PR-76-22, July 1976) ( ERIC Doc. No. 131 155); Slavin \& Maddin, School Practices that Improve Race Relations: A Reanalysis (Johns Hopkins University Center for Social Organization of Schools Report No. 264, Oct. 1978).

24. This section relies very heavily on a review of the relevant literature by Epps, The Impact of School Desegregation on the Self-Evaluation and Achievement Orientation of Minority Children, 42 LAw \& Contemp. Prob., Summer 1978, at 57. Another comprehensive overview of this question is provided by Jean Ann Linney, A Multivariable, Multilevel Analysis of a Midwestern City's Court Ordered Desegregation, at 31-37 (Ph.D. Dissertation, University of Illinois at Urbana-Champaign, 1978). 
ness to associate with other Hispanics. ${ }^{26}$ Even if bilingual programs generally have positive consequences, ${ }^{27}$ it may be that desegregation would contribute more in the long run to achievement gains and employment opportunities for minorities and better race relations. In short, it is difficult to know from the research whether the myth is true or false with respect to Hispanics.

The myth that desegregation of blacks negatively affects their self-concept and racial identity is unsupported, in general, by the research, but it is possible to specify conditions under which the myth may have some validity. Edgar Epps, who recently reviewed the relevant research, concludes that there is no necessary relationship between self-concept and racial identity. ${ }^{28}$ Thus, these two questions should be separated.

At the outset, it should be noted that there do not appear to be any significant overall differences between blacks and whites in the various measures of self-concept once socioeconomic background is controlled for. The available evidence suggests that desegregation may result in some initial disorientation in the self-esteem of black children, but that this is usually resolved over time. ${ }^{29}$

It seems likely that the particular desegregation strategies pursuedespecially in classrooms-affect the impact of desegregation on the self-concept of blacks. ${ }^{30}$ In most desegregated school systems, black children move from predominantly black to predominantly white schools. Moreover, in most cities desegregation results in proportionately more black than white children attending a new school, and thus it would be surprising if the shortrun anxiety and self-doubt some researchers have found among transferred minority students did not occur. Teachers who are sympathetic and responsive to minorities apparently do much to abate initial concerns. And, again, black children in overwhelmingly white schools may have more trouble with self-esteem than do black children who have at least a small number of black peers in each class with which to identify. ${ }^{31}$

25. H. Gerard \& N. Miller, supra note 21 , at 180 .

26. See id. at 213-29.

27. The most extensive study of bilingual education, whose methodology has been criticized even more than that of most major studies, found that bilingual education did not enhance achievement. American Institutes for Research, Evaluation of the Impact of ESEA Title ViI Spanish/English Bilingual Education Program (1977). For a succinct discussion of bilingual programs and their impact, see T. P. Carter \& R. Segura, Mexican Americans in School: A Decade of Change 328-70 (1979).

28. Epps, supra note 24 , at 57 .

29. See $i d$. at 57 . There is a great deal of variation in the definitions researchers give to selfconcept and how they measure it. This problem obviously makes generalizing from the research difficult.

30. This generalization is inferred from a large body of research on the importance of teacher behavior in shaping student self-esteem. See generally J. Brophy \& T. Good, TeacherStudent Relationships: Causes and Consequences (1974).

31. See Armor, The Evidence on Busing, 28 PuB. InTERest 90 (1972), a much publized study 
One might also infer from the research that classrooms that are highly competitive academically are likely to have more negative effects on lower achieving children than less competitive classrooms do. At the same time, tracking or extensive grouping by ability tends to lead to resegregation within the school or classroom and to give institutional approval to the idea that blacks have inferior academic abilities. This finding, however, is usually reported in studies of younger children, and some students of desegregation have argued that where achievement gaps between blacks and whites are especially great, some ability grouping may be appropriate for older children. ${ }^{32}$ For example, in high school courses such as math and language arts in which the bulk of the higher achieving students are of one race, each race will resent the other's level of performance, and low achievers are likely to feel particularly frustrated at the possibility of raising their own performance to the level of their high achieving classmates. The research is inadequate to resolve this issue, but a rigid tracking system would almost certainly reduce interracial contact and the benefits of desegregation.

There has been little research on the impact of desegregation on racial identity. Epps's review indicates that: (1) despite the fact that black children are aware that society as a whole may value white skin color more than black, they do not, in general, have race-related, negative images of themselves or other blacks; and (2) desegregation has no systematic effect on the racial identity of blacks. ${ }^{33}$ With respect to the second of these conclusions, it may be that black children in predominantly white schools become more conscious of their racial identity over time. ${ }^{34}$

\section{Myth IV:}

Busing children beyond the school nearest their home is harmful in terms of their performance in school, destructive of a sense of community cohesion, and very expensive financially

Understandably, when confronted with the possibility that their children will be bused to attain desegregation, parents worry that such busing will be a

which argued that busing children from central cities to suburban schools was harmful to their self-esteem and racial identity. While this study has been subjected to an unusual number of telling criticisms of its methodology, it may be noted that the programs studied typically placed black children in overwhelmingly white schools and classrooms.

32. For a summary of studies supporting and opposing ability grouping in high school, see Alexander, Cook \& McDill,Curriculum TrackingandEducationalStratification: SomeFurtherEvidence, $43 \mathrm{AM}$. Soc. Rev. 47, 64 (1978).

33. Epps, supra note 24 , at 57.

34. This was a finding of the Riverside study. See H. Gerard \& N. Miller, supra note 21 , at 162-63, 237. However, this measure of racial identity, which involves the choice of persons with whom to do school work and to play, may not be an appropriate measure of pride concerning one's race. 
hardship. However, most studies that have sought to provide answers to this concern indicate that busing itself has no adverse effects on learning. James Davis, after looking at data from a large number of desegregated Southern school districts, concludes that "there is no evidence that busing per se has any negative consequences," and that "there is no evidence that attending one's own neighborhood school has any effects, positive or negative, on a school's achievement levels or social climate." 35 To be sure, there is something counterintuitive about such conclusions, and the matter deserves further study. It seems reasonable to assume that riding buses for extended periods of time would be tiring and could take children away from other beneficial activities. Nonetheless, it also seems likely that we have romanticized the virtues of the neighborhood school. And, as should by now be well known, riding the bus is safer than walking to school.

There appears to be no systematic research on the impact of busing on the social structure and cohesion of neighborhoods. Based on preliminary findings in the Louisville study, it is likely that other institutions, such as churches and synagogues, are more fundamental to community life than the school. ${ }^{36}$ Moreover, it may be that schools drawing children from outside neighborhoods can continue to serve as neighborhood centers when they provide a range of community services (such as community recreation, library facilities, and activities for senior citizens). But for the time being all we can do is speculate about the impact of desegregation on the quality of life in neighborhoods. Surely the impact will vary from communities like Boston, with its tradition of ethnically identified subcommunities of considerable residential stability, to places like Los Angeles or Houston or most suburban school districts, where the major social function of a neighborhood is to facilitate the giving of directions to one's home.

While the financial costs of busing to achieve desegregation will vary, most opponents of busing seem to exaggerate the level of additional expenses involved. Gary Orfield reviews what is known about such expenses and finds that, on the average, desegregation increases a school district's budget less than 2 percent. ${ }^{37}$ Ironically, opponents of desegregation have prohibited the use of federal funds to support the cost of busing for desegregation but have been unable to restrict court-ordered desegregation that requires busing for implementation.

35. Davis, Busing, in 2 National Opinion Research Center, Southern Schools: An Evaluation of the Effects of the Emergency School Assistance Program and of Desegregation 118 (1973) (ERIC Doc. No. 084 426) [emphasis in original].

36. This research was conducted by John McConahay and Willis D. Hawley in 1976-77. The particular evidence on neighborhood cohesion is derived from unpublished preliminary analysis of the data.

37. G. Orfield, Must We Bus? 131 (1978). 
In sum, the research applicable to the issues raised by Myth IV provides little support for the notion that busing, in itself, has harmful consequences.

\section{E. Myth V:}

Desegregation does not enhance the post-high school opportunities and socioeconomic status of minorities

Because desegregated schooling generally enhances the achievement of minorities, probably improves their confidence in dealing with whites, and, at the least, does not reduce self-esteem and motivation to achieve, desegregation should lead to greater opportunities and capabilities to achieve in higher education and employment.

Overall, the rates of college enrollment and graduation for minorities have increased during the last several years. Moreover, black high school graduates are more likely than white graduates of comparable social class backgrounds to enroll in postsecondary institutions. ${ }^{38}$ However, definitive comparative continuation rates are not available, and blacks tend to enroll in two-year colleges and nonselective institutions in disproportionate numbers. ${ }^{39}$

The economic condition of minorities seems to have been enhanced substantially in recent years. As James McPartland observes, "Although large racial differences remain in employment, family incomes, personal earnings, and occupational level, there was significant progress during the prosperous 1960s toward narrowing these black-white gaps, and this progress has not been negated by the general problems in the economy of the 1970s."40

Though it would be inappropriate to assert that school desegregation was the direct cause of the improved economic conditions and educational achievements of minorities, ${ }^{41}$ it is unlikely that these gains would have occurred if desegregation had increased racial tensions and led to decreased minority opportunities overall.

However, the empirical evidence relating directly to Myth $\mathrm{V}$ is very sketchy. It appears that only two data sets allow a reasonably satisfactory test of the proposition that school desegregation affects the postschool experience and behaviors of adults. Several studies have worked with the first data set, ${ }^{42}$

38. McPartland, Desegregation and Equity in Higher Education and Employment: Is Progress Related to the Desegregation of Elementary and Secondary Schools?, 42 LAW \& Contemp. Prob., Summer 1978, at 108 \& n.7.

39. Id. at 108 .

40. Id. at 108. See Farley, Trends in Racial Inequalities: Have the Gains of the 1960s Disappeared in the 1970s?, 42 Aм. Soc. Rev. 189 (1977); Freeman, Black Economic Progress Since 1964, 52 PuB. INTEREST 52 (1978).

41. Other possible explanations for black attainments are the civil rights movement's impact on employment opportunity, decreases in prejudice among whites, and changes in the aspirations and self-confidence of minorities. Of course, school desegregation could have affected each of these factors.

42. U.S. Comm'n on Civil Rights, 1 Racial Isolation in the Public Schools (1967). 
which was collected in a 1966 retrospective survey of black and white adults living in Northern and Western metropolitan areas who had experienced desegregated schooling between 1930 and the early sixties. Collectively, these studies found that black men who had attended desegregated or predominantly. white schools were more likely than those who had attended segregated schools to hold nontraditional jobs in sales, crafts, and the professions and were more likely to have higher occupational prestige and income (though the differences here were small). As adults, both blacks and whites from the desegregated schools were more likely than those from segregated schools to choose desegregated housing and to have children in desegregated schools and close friends of the other race. ${ }^{43}$ Blacks from the desegregated schools also tended to have a stronger sense of opportunity and more confidence in their ability to succeed in interracial situations than did blacks from the segregated schools. ${ }^{44}$

Braddock and McPartland have examined data from the National Longitudinal Study of the high school graduating class of 1972 and concluded that:

1. Whether or not one attends a desegregated school seems to have little effect on college attendance or persistence.

2. Minority students who attend a desegregated high school, especially if they attended a racially mixed elementary school, are more likely to attend and to persist in predominantly white colleges. ${ }^{45}$

In summary, Myth $\mathrm{V}$ is not supported by the evidence. What information we have suggests that school desegregation enhances the opportunities minorities have for upward social mobility.

\section{F. Myth VI:}

Desegregation leads to white flight, reducing the social class and racial heterogeneity of communities, and thus eliminates the long-run opportunities for racial desegregation

No other concern so dominates the current debate over school desegregation as does the argument over desegregation's impact on the flight of whites from public schools. What does the available research tell us about this issue? Among the key findings Christine Rossell has recently summarized are the following:

1. School desegregation accelerates the long-term decline in white public school enrollment in the implementation year if white students are re-

43. McPartland, supra note 38 , at $108 \& \mathrm{nn} .72-74$.

44. Id. at 108 .

45. J. Braddock \& J. McPartland, The Perpetuation of Segregation from Elementary Schools to Higher Education (paper presented to the American Educational Research Association Annual Meeting, April 1979). The National Longitudinal Study is described in W. FetTers, supra note 5. See also McPartland, supra note 38, at 108 . 
assigned to formerly black schools or if a school system is over 35 percent black. This implementation-year loss may be made up in postimplementation years in school systems less than 35 percent black, or under countywide plans. In systems with a high proportion of black students, the initial loss is not made up, at least by the fifth year, though its initial impact is somewhat absorbed by lower losses over time.

2. Phasing in a plan results in more white flight from desegregation, because it gives affected families more time to find alternative housing or schooling.

3. Metropolitan plans reduce white flight, because they largely close out the option of a residential move to escape busing.

4. Voluntary plans typically cause little or no protest or white flight, because they result in little desegregation.

5. The more negative the newspaper coverage of desegregation and the schools, the greater the white flight.

6. White reassignments to formerly black schools result in substantially more white flight than do black reassignments to formerly white schools. ${ }^{46}$

In short, the research on white flight suggests that mandatory desegregation will lead to increasingly black or Hispanic school systems in some cities, but certainly not in all cities. There may be ways to design desegregation plans in communities where white flight threatens the economic base and long-term social heterogenity to reduce the incentives to leave the public schools.

First, and most obvious, curriculum changes or magnet schools could be implemented as part of a mandatory plan. Second, a two-stage reassignment process could be employed instead of the random assignment process typically used. That is, since most of the white flight is related to white reassignment to black schools, an attempt could be made to determine which white parents would be willing to enroll their child in a formerly black school if the curriculum were unique or of high quality. When all the white children who will volunteer for magnet schools in black neighborhoods have done so, the rest will receive mandatory reassignments.

It may be that the racial stability of school systems can be encouraged by plans that leave portions of the system predominantly black or Hispanic. ${ }^{47}$ It

46. Rossell, supra note 15 , at 133-183.

47. This suggestion does not, however, take into account whether such a desegregation plan would be a permissible remedy for a proven constitutional violation. See, e.g., Morgan v. Kerrigan, 401 F. Supp. 216, 233-34 (D. Mass. 1975). In Morgan, the panel of masters heard expert testimony that desegregation would cause white flight but dismissed the contention as a "mis- 
is already the case that school desegregation can only be achieved in some systems by leaving some schools racially isolated. Racial stability of schools might be enhanced if parents were given guarantees that the racial balance of a school, perhaps at a 50-50 level, would be maintained even in the face of districtwide changes in racial composition. Such experiments and evaluation of them seem important.

And programs like those in effect in Massachusetts, Wisconsin, and Delaware that encourage voluntary interdistrict transfers to foster desegregation can be promoted. ${ }^{48}$ Metropolitanwide plans largely eliminate residential flight related to desegregation, and some regions could thus achieve substantial desegregation without massive busing.

But what is one to make of the argument that the likelihood of white flight is reason enough to resist mandatory desegregation so that school desegregation will be possible in the future? The assertion that we should postpone efforts to achieve civil rights until a better time has an unsettling deja vu quality about it. When will desegregation not lead to white flight? What processes will bring that day about? School desegregation substantially increases interracial contact among school-age children; without such interaction, how is interracial hostility to be mitigated? Paradoxically, increases in interracial contact are substantial in the school systems with high minority enrollments, which also experience the greatest white flight. ${ }^{49}$ As long as ten years after desegregation, districts with extensive, two-way reassignment plans have two to three times the interracial contact of districts that have not desegregated. ${ }^{50}$

Finally, it is important to note that the growth of the black population in the cities has halted for the first time since World War II, and black migration to the suburbs has also increased. ${ }^{51}$ In some metropolitan areas, there is some movement of whites back to the cities. Whether the public schools can respond to these opportunities remains to be seen.

\section{III}

\section{Origins and Persistence of the New Myths}

A remaining question is: Why has this mythology emerged and how is it sustained? There are at least four explanations worthy of brief comment: (1)

\footnotetext{
leading fiction." Id. at 233 n.7. But see Calhoun v. Cook, 362 F. Supp. 1249 (N.D. Ga.), remanded, 487 F.2d 680 (5th Cir. 1973).

48. For descriptions of these programs, see G. ORFIELd, supra note 37, at 442-43; McPartland, supra note 38, at 108-132; Coleman, supra note 1 , at 5 .

49. Rossell, supra note 15 , at 133.

50. Coleman, Kelly \& Moore, Trends in School Segregation, 1968-73, at 75 (1975) (Urban Institute Working Paper No. 722-03-01). See also Rossell, supra note 15, at 133.

51. Announcement of the U.S. Census Bureau, reported in McBee, Growth of the Black Population in Cities Halts, Wash. Post, Dec. 1, 1978, § A, at 13.
} 
misinterpretation of the research, (2) the usefulness of the mythology to those resisting change and racial justice, (3) the combination of disillusionment and racial pride among minorities, and (4) the "failure" of the old mythology, which placed desegregation at the heart of contemporary liberalism.

\section{A. Misinterpretations of the Research}

There are several reasons why many people have tended to misinterpret the research on school desegregation. First, the incentives to misstate or overstate research findings have increased. Social science research has become an increasingly significant factor in shaping public policies; this often puts researchers and their interpreters in adversarial roles that involve pressures both to be "clearer" than the findings warrant and to take sides. Once an individual is identified with a position, both supporters and critics create incentives for the individual to justify his or her position. This has often meant that those who have found evidence that school desegregation has not maximized its potential are recruited to a battle once fought primarily on moral grounds. In confronting those who claim morality as their justification, one may claim more for the empirical base of one's position than is appropriate.

Second, not enough attention is given to the reasons for different findings. Some of those who interpret the research use a "body count" approach to explaining the results of the studies. For example, many studies concluding that the effects of desegregation on achievement are insignificant or negative involve black youngsters in the first year of desegregation or those who experienced desegregation only at high-school age.

Third, methodologically weak studies appear more likely than stronger studies to show negative or insignficant findings. ${ }^{52}$ Many reviews fail to take this fact into account in summarizing the studies. ${ }^{53}$

Finally, many scholars and reviewers establish inappropriate standards for determining when desegregation has been beneficial. For example, many of those studying race relations measure success against a standard that would require that race be totally irrelevant in determining interpersonal interaction.

\section{B. The Usefulness of the Research in Resisting Change and Racial Justice}

Some misinterpretations of the research are the result of selective reviews and analyses of the evidence. Some of those who have always opposed

52. See Crain \& Mahard, Desegregation and Black Achievement, supra note 3, at 17-56; Hawley, Getting the Facts Straight About the Effects of School Desegregation, 36 EDuc. LeadershiP 314, 315-16.

53. A recent example is Walter Stephan's discussion of the research on race relations, Stephan, School Desegregation: An Evaluation of the Predictions Made in Brown v. Board of Education, 85 Psych. Bull. 217 (1978). 
desegregation have seized on the findings that have raised questions about the success of desegregation efforts. In the process, the fundamental justification for desegregation-the promotion of racial and social equality-is submerged. The commitment many of us have to racial justice has always been fragile because of the possibilities that such change will be at our expense. ${ }^{54}$

\section{Ambivalence Among Minorities}

The new mythology is strengthened by some minority leaders' ambivalence about desegregation. School desegregation has not brought all the benefits they had hoped for, and the struggle now appears less justifiable to them than it did in more hopeful times. Some Hispanics see school desegregation and bilingual education as competing objectives. Also, some blacks, Hispanics, and Native Americans see an all-out commitment to desegregation in the absence of de jure segregation as a belief that minorities need whites to be successful. Gary Orfield, however, offers a response to this concern that focuses on the costs of discrimination.

It is not . . the belief that there is something wrong with blacks that makes desegregation necessary but the fact that there has been and continues to be something very wrong with the way that society treats black and Hispanic people and their schools. Much of the existing intense segregation of metropolitan schools is not a product of choice by blacks, who prefer integration by a very large margin, but of public and private discrimination that created and expanded ghettos and barrios. ${ }^{55}$

\section{The Failure of the Old Myth}

Perhaps old myths that have lost their credibility are the best fuel to ignite countermyths. The old mythology served important functions in mobilizing the early efforts to desegregate not only the schools but all aspects of society. The problem with the old mythology of desegregation is that it promised too much. It was naive to imagine that "black and white together"-with its many variations-would bring an end to inequalities and prejudices deeply rooted in cultures and institutions. Perhaps the rejection of the old mythology by some liberals results from their discomfort with what the desegregation experience has told us about the possibilities of social change and the significance of class and race in American life. To some, the school desegregation experience has been a bitter pill to swallow.

54. Cf. McConahay \& Hawley, Is it the Buses or the Blacks?: Self-Interest Versus Symbolic Racism as Predictors of Opposition to Busing in Louisville (Sept. 1977) (Working Paper No. 977, Duke University Institute of Policy Sciences and Public Affairs) (self-interest is weakly and inconsistently related to opposition to busing; racial attitudes are much more closely related to antibusing attitudes).

55. Orfield, Letter to the Editor, The Chronical of Higher Education, Dec. 4, 1978, at 21. 


\section{IV}

\section{Dealing With the New Mythology}

For those who find the new mythology of school desegregation incompatible with their perceptions of reality and their hopes for the future, two steps may be useful. A first step in dealing with the new mythology is to examine its evidentiary base. I have attempted this here, but additional research is needed to clarify several matters. Besides dealing with issues that are now largely neglected (such as the Hispanic experience), new research needs to give greater attention to (1) the nature of the experiences children have in the desegregation process, (2) the magnitude as well as the direction of the outcomes, and (3) greater methodological rigor. These research priorities will facilitate comparison of findings across studies and will allow us to feel more confident generally about using the research as a guide to public policy.

Second, greater clarification of the goals we have for desegregation and greater straightforwardness in presenting them is in order. One aspect of the old mythology was its apparent endorsement of the idea that school desegregation was an end in itself that could be simply defined and implemented. But even in cases where desegregation is the response to a clear constitutional denial of individual rights, the appropriate way to remedy such injustice will vary with the situation and with the needs of the students involved. Focusing attention on the goals we hope to achieve through desegregation might provide some basis for cooperation among people of all races and increase flexibility in the strategies embodied in desegregation plans and the ways they are implemented. Most important, greater attention to goals should move us from a preoccupation with "racial balance" per se to devising desegregation strategies that are effective in meeting the needs of students and the society and are seen as part of a larger set of educational and social policies.

\section{CONCLUSION}

It is time to move beyond the question of whether school desegregation can have positive outcomes for children and the society at large. There is ample evidence that desegregation-if implemented with commitment and awareness of the lessons of past experience-can be made to "work." Many of the things that we need to do to enhance the effectiveness of desegregation are known. And we can learn more if we care to. The processes that contribute to successful desegregation for the most part are steps that would improve schools in the absence of desegregation. This does not mean that it will be easy, of course. The fact that there are so few excellent schools, whether desegregated or segregated, testifies to the difficulties of making necessary changes. 
While it is desirable to know more about important desegregation issues, the central problem is not how to design an effective desegregated school, but how to implement the design. For example, how can teachers and principals be helped and encouraged to adopt appropriate behaviors? How can the support of parents be enlisted? Most important, how-in the absence of metropolitanwide school systems-can we desegregate cities with large minority populations without spurring further residential segregation? We need to add these and other questions related to implementation to our research and action agendas. No trade-offs need to be made between desegregation and quality education. We can have both! 
